\title{
Synergism between Polymyxin and Polysorbate 80 against Pseudomonas aeruginosa
}

\author{
By M. R. W. BROWN* AND B. E. WINSLEY \\ Pharmaceutical Microbiology Group, Bath University of Technology, \\ Bath, Somerset
}

(Accepted for publication 6 August 197I)

\begin{abstract}
SUMMARY
Polymyxin B and the non-ionic surfactant polysorbate 80 acted synergistically against Pseudomonas aeruginosa with respect to leakage, death and lysis. Polysorbate 80 alone was non-toxic. The enhancement of polymyxin occurred throughout the polysorbate concentration range (0.000 I to $0.250 \%, \mathrm{v} / \mathrm{v})$. No sudden change in the pattern of enhancement occurred near the critical micelle concentration of polysorbate. The onset of action of polysorbate was prompt, implying a direct physical effect on the bacteria. Exposure of bacteria to this surfactant did not cause an increase in uptake of polymyxin. It is proposed that polysorbate 80 alters the outer lipid structure of the envelope of $P$. aeruginosa allowing easier access of polymyxin to the underlying membrane.
\end{abstract}

\section{INTRODUCTION}

Concentrations of about $0.02 \%$ of the non-ionic surface active agent polyoxyethylene sorbitan mono-oleate (polysorbate 80) rendered Pseudomonas aeruginosa more sensitive to chlorhexidine, benzalkonium and polymyxin B (Brown \& Richards, I964). Increase in concentration of polysorbate 80 eliminated this effect with chlorhexidine and benzalkonium but not with polymyxin $\mathrm{B}$. The former compounds probably interacted with polysorbate either by complex formation (Guttman \& Higuchi, 1956) or by solubilization within the micelles of the non-ionic agent (Goodhart \& Martin, 1962). Brown \& Winsley (1969) found that polysorbate 80 had an immediate effect on the permeability barrier of the bacteria, rendering them more sensitive to rapid changes in $\mathrm{pH}$, temperature or tonicity. There was direct evidence from dye penetration studies that polysorbate 80 altered the structure of the envelope. The present paper reports further work on the enhancement of action of polymyxin B by polysorbate 80 against $P$. aeruginosa.

\section{METHODS}

Organism. Pseudomonas aeruginosa NCTC6750 was maintained on nutrient agar slopes (Oxoid) at $4^{\circ}$ and cultured in nutrient broth no. I (Oxoid) at $37^{\circ}$. In some experiments the following defined medium was used for culture and maintenance: 0.00I $\mathrm{M}-\left(\mathrm{NH}_{4}\right)_{2} \mathrm{SO}_{4}$; $0.006 \mathrm{M}-\left(\mathrm{NH}_{4}\right)_{2} \quad \mathrm{HPO}_{4} ; 0.004 \mathrm{M}-\mathrm{NH}_{4} \mathrm{H}_{2} \mathrm{PO}_{4} ; 0.0 \mathrm{I} \mathrm{M}-\mathrm{NaCl} ; 0.0 \mathrm{I} \mathrm{M}$-glucose (autoclaved separately in concentrated solution) $; 4 \times 10^{-6} \mathrm{M}^{-\mathrm{Mg}^{2+}}\left(\right.$ added as $\left.\mathrm{MgSO}_{4} \cdot 7 \mathrm{H}_{2} \mathrm{O}\right)$, dissolved in distilled water and autoclaved at $\mathrm{I} 5 \mathrm{lb} / \mathrm{sq}$.in. for $10 \mathrm{~min}$; $\mathrm{pH} 7 \cdot 4$.

Polymyxin B sulphate ('aerosporin'- Burroughs Wellcome Ltd, Beckenham, Kent) was dissolved in sterile $\mathrm{CO}_{2}$-free distilled water.

\footnotetext{
* Present address: Department of Pharmacy, The University of Aston in Birmingham, Birmingham 4.
} 
Polysorbate 80 ('Crillet 4' - Croda Ltd, London W.C.I.) was dissolved in distilled water and autoclaved at $15 \mathrm{lb} / \mathrm{sq}$.in. for $10 \mathrm{~min}$.

Exponential-phase cultures were produced and their growth followed by extinction measurements at $420 \mathrm{~nm}$. $\left(E_{420}\right)$ of samples of the culture as described by Brown \& Richards (1964).

Total cell counts were made, after 'fixing' the bacteria in I \% formaldehyde solution, using haemocytometer slides of $0.1 \mathrm{~mm}$. depth (coefficient of variation of counting procedure $=4.2 \%$ ).

Viable counts were made on triplicate nutrient agar spread plates at $37^{\circ}$ for $48 \mathrm{~h}$. Nutrient broth at $18^{\circ}$ was used as diluent (coefficient of variation of the counting procedure was $4.3 \%$ ). When polymyxin was present, broth containing $0.2 \%$ egg lecithin to inhibit residual polymyxin was used.

Assay of polymyxin was by the method of Wintermere, Eisenberg \& Kirshbaum (1957) adapted as described in the following paragraphs. This depended on the inverse correlation between polymyxin concentration and growth rate at $37^{\circ}$ of Escherichia coli ATCC 10536 in a special medium.

Uptake of polymyxin from its solutions in broth by Pseudomonas aeruginosa was deduced by assaying the residual polymyxin after removing the bacteria by centrifugation. Polysorbate 80 in solution interfered with the Escherichia assay of polymyxin. Therefore the influence of polysorbate on cellular polymyxin uptake by $P$. aeruginosa was assessed by first equilibrating the bacteria with polysorbate in solution and then washing away surplus polysorbate before exposing the organisms to polymyxin solutions. Residual polymyxin was then assayed.

Leakage of $260 \mathrm{~nm}$.-absorbing constituents from bacteria in solutions of polymyxin and polysorbate in water or in defined medium was measured spectrophotometrically (Brown, Farwell \& Rosenbluth, I969; Brown \& Winsley, 1969). With solutions in defined medium, $5 \times 10^{8}$ bacteria $/ \mathrm{ml}$. were suspended at $37^{\circ}$ in the medium without added $\mathrm{Mg}^{2+}$, to avoid competition between $\mathrm{Mg}^{2+}$ and polymyxin for absorption by the cells (Newton, I954). Possible synergism (Garrett \& Brown, 1963) between polymyxin and polysorbate on cell leakage was tested by adding to $6 \mathrm{ml}$. samples of the cell suspension $0 . \mathrm{I} \mathrm{ml}$. amounts of water or concentrated solutions of polymyxin or polysorbate. To further samples, both compounds were added in graded amounts (as indicated on the axes of Fig. 6) using up to $0.125 \%$ polysorbate and $3 \mathrm{I} \cdot 25$ units polymyxin $/ \mathrm{ml}$. the concentrations causing separately the maximum leakage rates (Winsley, 1968; Brown \& Winsley, 1969).

\section{RESULTS}

\section{Effect of polysorbate 80 and polymyxin $B$ on viability and extinction}

The effect on extinction produced by adding polymyxin to an exponential-phase culture was sudden in onset (Fig. I). Parallel increases in viable and total cell counts and in $E_{420}$ occurred during exponential growth (Fig. 2). Within the range examined, this value was a measure of bacterial concentration. Adding polymyxin after $200 \mathrm{~min}$. incubation ( $\mathrm{Px}$, Fig. 2) lowered the viable counts to a level below the abscissa $\left(\mathrm{I} \times \mathrm{IO}^{6}\right.$ viable bacteria $/ \mathrm{ml}$. after $320 \mathrm{~min}$.) while the total count and $E_{420}$ value fell in parallel, indicating a true decrease by lysis of the bacterial concentration and not merely a change in cellular morphology or light-scattering properties (Bernheim, I963; Rye \& Wiseman, I968). Polysorbate $(<0.250 \%)$ did not alter the exponential growth rate, but greatly and progressively enhanced the action of polymyxin (added at Px, Fig. 3) on $E_{420}$ and, therefore, on bacterial 


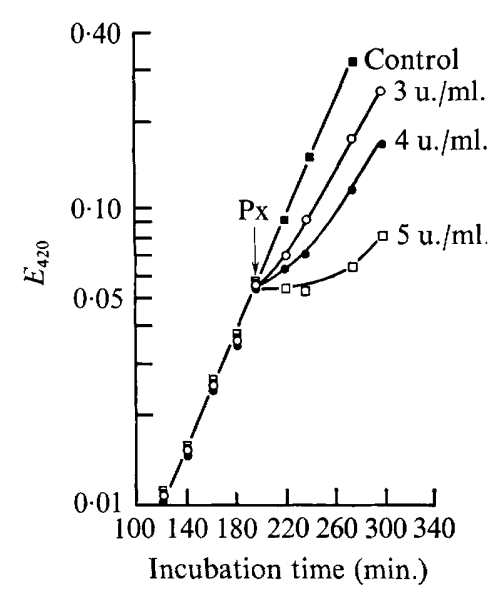

Fig. I

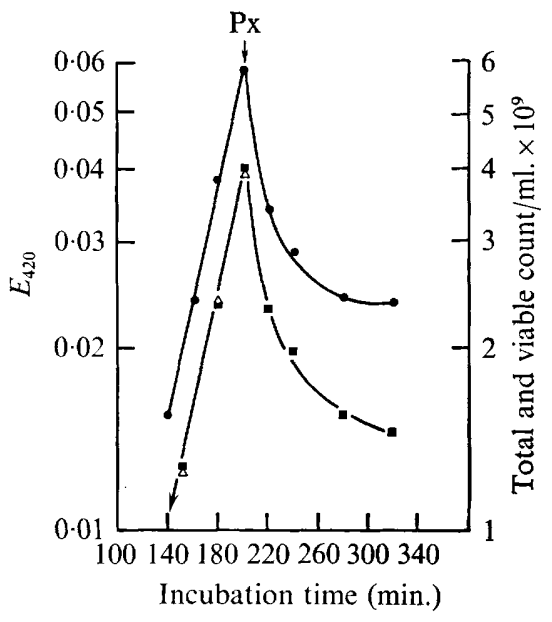

Fig. 2

Fig. I. Effect of polymyxin (3,4 or 5 units $/ \mathrm{ml}$.) on exponential-phase Pseudomonas aeruginosa in broth at $37^{\circ}$.

Fig. 2. Effect of polymyxin (5 units $/ \mathrm{ml}$.) on (i) extinction at $420 \mathrm{~nm}$. and (ii) total and viable counts of exponential-phase $P$. aeruginosa at $37^{\circ}$ in broth $+0.02 \%$ polysorbate. $\boldsymbol{O}, E_{420} v$. time; $\boldsymbol{\square}$, total count $v$. time; $\triangle$, viable count $v$. time.

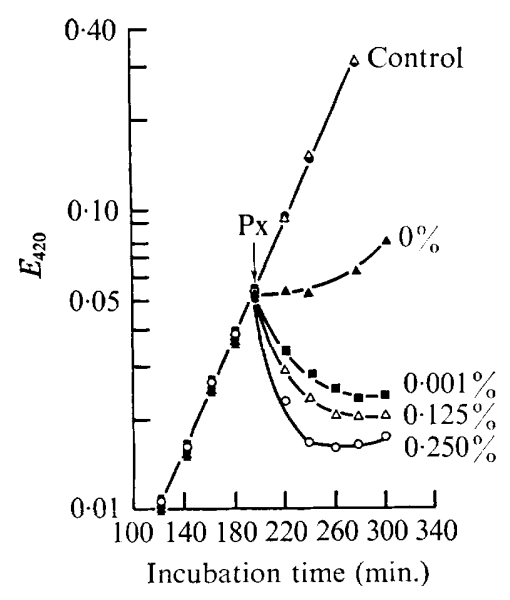

Fig. 3

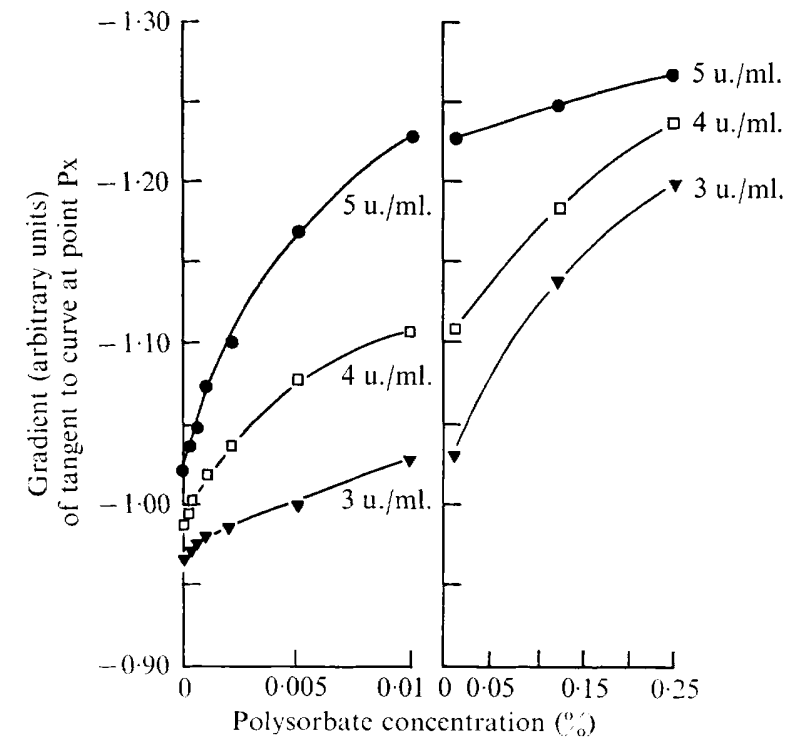

Fig. 4

Fig. 3. Effect of polysorbate concentration (o to $0.250 \%$ ) in broth at $37^{\circ}$ on the action of polymyxin $(5$ units $/ \mathrm{ml}$., added at $\mathrm{Px}$ ) on growth rate of $P$. aeruginosa.

Fig. 4. Effect of polysorbate concentration in culture broth at $37^{\circ}$ on the gradient of the $E_{420} v$. incubation time curves representing the action of polymyxin $(3,4$ or 5 units $/ \mathrm{ml}$.) on bacterial concentration (see Fig. 3). 
concentration. This experiment was repeated, using concentrations between o and 5 units polymyxin $/ \mathrm{ml}$. together with o to $0.250 \%$ polysorbate. The magnitude of effect of each combination was measured as the gradient of a tangent, passing through $\mathrm{Px}$, to the curve representing the characteristic $E_{420}$ decrease caused by that combination, i.e. the greater the effect, the steeper the decrease and the greater the negative value of the gradient. These effects are summarized in Fig. 4. A smooth increase in enhancement of polymyxin occurred with rising polysorbate concentration. No sudden change occurred at the critical micelle concentration (C.M.C.) of polysorbate in aqueous solution, $0.001 \%$ (Vidal-Paruta \& King I964), although the most rapid increase in effect took place between o and $0.01 \%$ polysorbate.

Fig. 5 illustrates the promptness of enhancement of polymyxin by polysorbate. The enhancement produced by simultaneous addition of the two agents (o min.) is very similar to that produced by adding polysorbate up to $\mathrm{I} 60 \mathrm{~min}$. prior to polymyxin (equal to several generations of the organism).

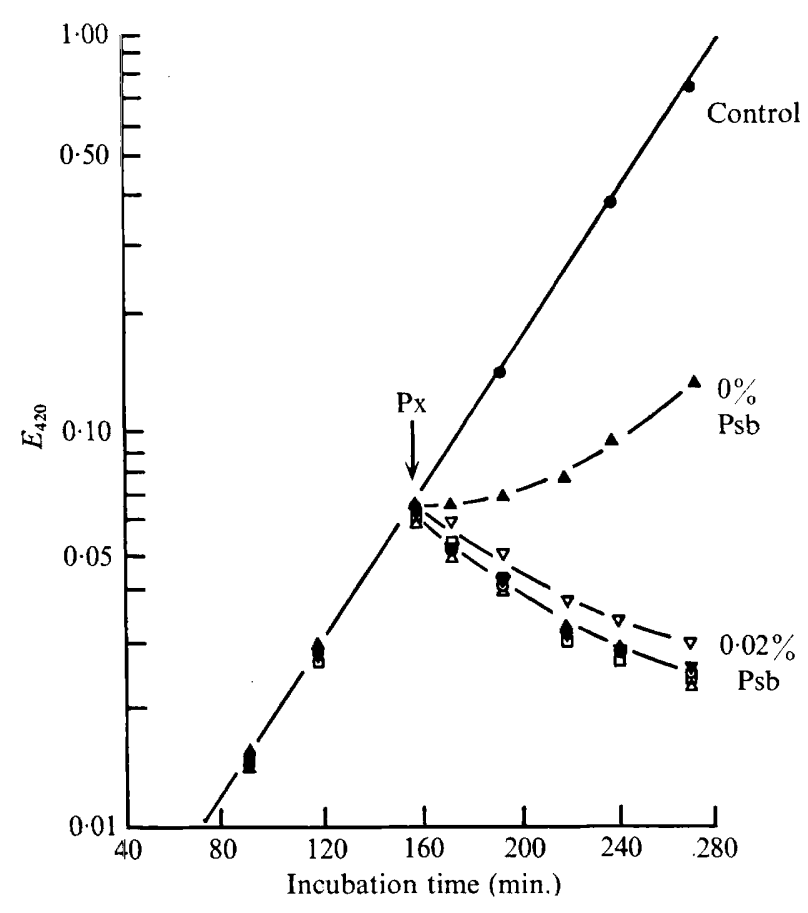

Fig. 5. Effect on bacterial concentration of length of time interval between the addition of polymyxin (5 units $/ \mathrm{ml}$.) at $\mathrm{Px}$, and of polysorbate (o or $0.02 \% \mathrm{Psb}$ ) to exponential-phase broth culture at $37^{\circ}$. Interval: $\nabla$, o min.; $\square$, It min.; $\triangle, 5$ min.; $\nabla, 30 \mathrm{~min} . ; \bigcirc, 60 \mathrm{~min}$.

\section{Effect of polysorbate 80 and polymyxin $B$ on leakage}

In defined medium, leakage increased with increasing concentration of both agents over the range examined (Fig. 6). In aqueous solution, maximum leakage occurred in $0.125 \%$ polysorbate or in $3 \mathrm{I} \cdot 25$ units polymyxin $/ \mathrm{ml}$. (Brown \& Winsley, I969). Adding to the cell suspensions submaximum, leakage-inducing concentrations of both agents ('observed mixture' curve) caused leakage substantially greater than that predicted by arithmetic addition of the leakages caused by each compound acting alone ('calculated mixture' curve). 
In control mixtures containing solutions of either agent and bacterial cell contents no combinations caused an unpredictable $E_{260}$. The unpredictable increase in $E_{260}$ indicated synergism between the two agents.

Fig. 7 shows the characteristic effects of polymyxin \pm polysorbate on both viability and leakage with bacteria in the defined medium without added $\mathrm{Mg}^{2+}$. To measure leakage, the bacteria were rapidly removed from the suspending medium by membrane filtration (Brown et al. I969). Leakage is plotted as the amount lost by leakage expressed as a percentage of the total $260 \mathrm{~nm}$--absorbing bacterial contents extractable by disintegration by shaking with Ballotini beads. Polysorbate alone had no significant effect on either parameter, but acted synergistically with polymyxin. The extent of lethal effect appeared not to correlate with the amount of $260 \mathrm{~nm}$.-absorbing substance lost by the bacteria. These results do not exclude the possibility of a relationship between the initial maximum rate of loss both of viability and of $260 \mathrm{~nm}$.-absorbing material.

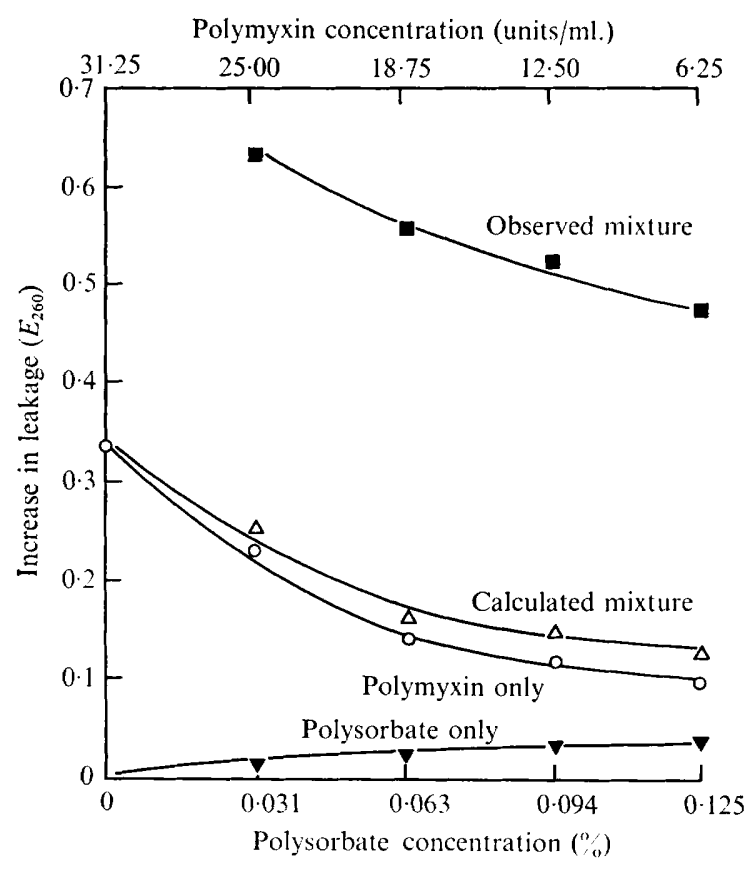

Fig. 6

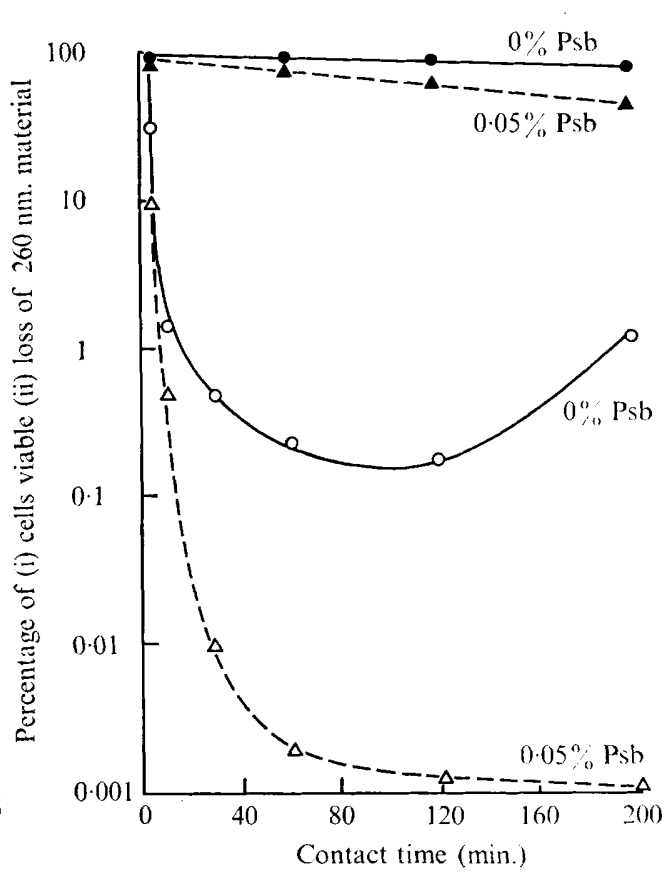

Fig. 7

Fig. 6. Increase in leakage of $260 \mathrm{~nm}$.-absorbing cell constituents effected by the action of polysorbate and polymyxin, individually or in various combinations, on bacteria suspended at $37^{\circ}$ in defined medium with no added $\mathrm{Mg}^{2+}$.

Fig. 7. Effect on viability and leakage of $260 \mathrm{~nm}$.-absorbing bacterial constituents with Pseudomonas aeruginosa at $37^{\circ}$ in defined medium without added $\mathbf{M g}^{2+}$ exposed to polymyxin (30 units $/ \mathrm{ml}$.) $\pm 0.05 \%$ polysorbate. Solid line, percentage viability; broken line, $260 \mathrm{~nm}$. loss.

\section{Uptake of polymyxin $B$ by bacteria}

The residual polymyxin in solution after exposure to Pseudomonas aeruginosa decreased with increasing bacterial concentration and, for a given bacterial concentration, with decreasing initial polymyxin concentration. Previous exposure to polysorbate had no measureable effect on the organism's ability to take up polymyxin from solution. 


\section{DISCUSSION}

Polysorbate 80 enhances the action of several compounds on various bacteria (Kirby \& Dubos, I947; Fisher, I948; Bliss \& Warth, 1950). Within the range we examined, polysorbate $(0.000 \mathrm{I}$ to $0.250 \%)$ increased the lethal leakage-inducing and bacterial-lysing actions of polymyxin (Fig. 3,6,7). Although there is no sudden change in the shape of the curve near the C.M.C. of polysorbate, the greatest rate of increase of enhancement with concentration occurred at or below this concentration (Fig. 4).

The promptness of onset of polymyxin enhancement by polysorbate implies a direct physical action of the latter on the bacteria, rather than one involving a gradual progressive metabolic incorporation. In a previous study (Brown \& Winsley, 1969) it was shown that polysorbate did not significantly alter the pronounced optical effect at various $\mathrm{NaCl}$ concentrations. Nevertheless, dye ( $l$-anilinonaphthylamine-8-sulphonic acid) uptake studies showed the polysorbate concentration causing greatest leakage also caused greatest uptake of dye which probably was at a site in the envelope. These results and the lack of effect on growth rate suggest a subtle effect of polysorbate. In contrast, growth of polysorbatetreated tubercle bacilli was stimulated, presumably resulting from the easier entry of nutrient into the cells (Fletcher, Epstein \& Jewell, 1953). An increased permeability of various micro-organisms after polysorbate treatment has been reported (Dastugue, Bastide \& Decros, 1959; Paunescu, Cialac-Negolscu \& Pisica, 1964; Reese \& Maguire, 1969).

The cell membrane is probably the main site of action of polymyxin (Newton, I958). As polysorbate and polymyxin act synergistically on viability and permeability, these agents probably have different sites of action. Lacey (1958) suggested that synergism between compounds indicated a difference in mode of action. Contact with polysorbate changed the lipid characteristics of various bacteria (Bloch \& Noll, I953; Godson \& Sinsheimer, I967; Lorain, 1967) and similar changes in the lipid containing envelope structure of Pseudomonas aeruginosa could account for the phenomena reported in this paper. Pseudomonas aeruginosa cell wall lipid (and cation) has been implicated in polymyxin resistance (Brown \& Melling, I969; Brown \& Watkins, I970). The synergism reported here does not exclude the possibility of polysorbate and polymyxin B both acting in different ways on the cytoplasmic membrane. It seems more likely that polysorbate altered the lipid structure of the envelope at sites relatively external to the cytoplasmic membrane, allowing easier entry of polymyxin to the underlying membrane, its main site of action.

The authors are very grateful to the Medical Research Council for a grant supporting this work.

\section{REFERENCES}

BernheIm, F. (I963). Factors which affect the size of organisms and the optical density of suspensions of Pseudomonas aeruginosa and Escherichia coli. Journal of General Microbiology 30, 53-58.

BuIss, E. A. \& WARTH, P. T. (1950). The effect of surface-active agents on antibiotics: an informal report. Proceedings of the New York Academy of Science 53, 38.

BLoch, H. \& NolL, H. (1953). Studies on the virulence of tubercle bacilli. Variations in virulence affected by Tween 80 and thiosemicarbazone. Journal of Experimental Medicine 97, I-16.

Brown, M. R. W., Farwell, J. A. \& Rosenbluth, S. A. (1969). Use of membrane filters for measurement of $260 \mathrm{~m} \mu$ absorbing substances from bacterial cells. Analytical Biochemistry 27, 484-49I.

Brown, M. R. W. \& Melling, J. (1969). Role of divalent cations in the action of polymyxin B and EDTA on Pseudomonas aeruginosa. Journal of General Microbiology 59, 263-274.

Brown, M. R. W. \& Richards, R. M. E. (1964). The effect of Tween 80 on the resistance of Pseudomonas aeruginosa to chemical inactivation. Journal of Pharmacy and Pharmacology 16, 5I-55. 
Brown, M. R. W. \& WATKINS, W. (1970). Low magnesium and phospholipid content of cell walls of Pseudomonas aeruginosa resistant to polymyxin. Nature, London 227, 1360-136I.

Brown, M. R. W. \& Winsley, B. E. (1969). Effect of polysorbate 80 on cell leakage and viability of Pseudomonas aeruginosa exposed to rapid changes of $\mathrm{pH}$, temperature and tonicity. Journal of General Microbiology 56, 99-107.

Dastugue, G., Bastide, P. \& Decros, M. (I959). Influence of some surface-active agents on membrane permeability. In studies with larvae of amphibia. Année pharmaceutique 17, 269-278.

FISHER, M. W. (1948). Sensitivity of tubercle bacilli to streptomycin. American Review of Tuberculosis and Pulmonary Diseases 57, 58-62.

Fletcher, F., Epstein, C. \& Jewell, P. I. (1953). The antimycobacterial activity of tissue extracts and surface-active agents in Dubos's medium. Journal of General Microbiology 8, 323-329.

Garrett, E. R. \& Brown, M. R. W. (1963). The action of tetracycline and chloramphenicol alone and in admixture on the growth of Escherichia coli. Journal of Pharmacy and Pharmacology 15, I85-191.

Godson, G. N. \& SinSheImer, R. L. (1967). Lysis of Escherichia coli with a neutral detergent. Biochemica et biophysica acta $\mathbf{1 4 9}, 476-488$.

Goodhart, F. W. \& Martin, A. N. (1962). Solubilization of benzoic acid derivatives by polyoxyethylene stearates. Journal of Pharmaceutical Sciences 5r, 50-54.

Guttman, D. \& Higuchi, T. (I956). Possible complex formation between macromolecules and certain pharmaceuticals X. Journal of the American Pharmaceutical Association. Scientific Edition 40, 390-393.

KIRBy, W. W. M. \& Dubos, R. J. (I 947). Effect of penicillin on the tubercle bacillus in vitro. Proceedings of the Society for Experimental Biology and Medicine 66, 120.

LaCeY, B. W. (1958). Chemotherapeutic Synergy. 8th Symposium of the Society for General Microbiology. Cambridge: Cambridge University Press.

Lorian, V. (I967). Comparison of mycobacterial cultures on agar and Lowenstein medium. Applied Microbiology 15, 1202-1 205.

Newton, B. A. (1954). Site of action of polymyxin on Psedomonas aeruginosa: antagonism by cations. Journal of General Microbiology ro, 49 I-499.

Newton, B. A. (1958). Surface-active bactericides. 8th Symposium of the Society for General Microbiology. Cambridge: Cambridge University Press.

Paunescu, E., Cralac-Negolscu, A. \& Pisica, G. (1964). The effect of Tween 80 and penicillin on the physiochemical properties of the cell wall in mycobacteria. Studii şi Cercetări de Biochimie. Academie Republicii Populare Romane. 7, 83-89.

ReESE, E. T. \& MAguiRe, A. (1969). Surfactants as stimulants of enzyme production by micro-organisms. Applied Microbiology $\mathbf{7}(2), 242-245$.

Rye, R. M. \& Wiseman, D. (1968). Cell size change during growth of Escherichia coli partially inhibited by some antibacterial agents. Journal of Pharmacy and Pharmacology 2o, Suppl. 8S.

VIDAL-PARUTA, M. R. \& KING, L. D. (I964). Critical micelle concentration of non-ionic surfactants in water and carbon tetrachloride. Journal of Pharmaceutical Sciences 53, 1217-1219.

WINSLEY, B. E. (1968). Studies on the effect of polysorbate 80 on the resistance of Pseudomonas aeruginosa. Ph.D. Thesis, University of Bath.

Wintermere, D. M., Eisenberg, W. H. \& Kirshbaum, A. (1957). Turbidimetric assay of tetracycline, chlortetracycline, oxytetracycline, chloramphenicol, neomycin and polymyxin using a single organism. Antibiotics and Chemotherapy, 7, 190-192. 